\title{
KOMPARASI PENGARUH ARUS KAS TERHADAP NILAI PERUSAHAAN ANTARA PT HERO SUPERMARKET TBK DENGAN PT MATAHARI PUTRA PRIMA TBK
}

\author{
Retno Martanti Endah Lestari \\ Dosen Tetap Fakultas Ekonomi Universitas Pakuan \\ Lecturer of Economic Faculty at Pakuan University \\ Putri Puspita Sari \\ Mahasiswa Fakultas Ekonomi Universitas Pakuan \\ Student of Economic Faculty at Pakuan University
}

\begin{abstract}
ABSTRAK
Mereka menggunakan laporan keuangan perusahaan untuk mengukur kinerja perusahaan, sehingga mereka tahu bagaimana arus kas perusahaan, dan juga dapat menganalisis dan memprediksi potensi keuangan yang dimiliki oleh perusahaan. Metode analisis yang digunakan menggunakan regresi linier berganda. Kesimpulan dari penelitian ini menunjukkan bahwa arus kas simultan atau sebagian tidak mempengaruhi nilai perusahaan. Perbandingan dari dua perusahaan, dalam hal arus kas berdasarkan aktivitas total selama 2009, 2010 dan 2013 PT Matahari Putra Prima Tbk unggul PT Hero Supermarket Tbk, sedangkan untuk 2 tahun 2011-2012 PT Hero Supermarket TBJ yang total superior aktivitas operasi dibandingkan dengan PT Matahari Putra Prima Tbk. Kemudian berdasarkan aktivitas total investasi, PT Matahari Putra Prima Tbk unggul PT Hero Supermarket Tbk dan berdasarkan total aktivitas pendanaan PT Hero Supermarket Tbk unggul Mathari PT Putra Prima Tbk. Pada tahun 2009 dan pada tahun 2013, PT Matahari Putra Prima Tbk rasio hasil nilai harga-buku (PBV) lebih tinggi dari PT Hero Supermarket Tbk, sedangkan di 2010-2012 PT Hero Supermarket Tbk, yang memiliki rasio PBV yang lebih tinggi bila dibandingkan dengan PT Matahari Putra Prima Tbk.
\end{abstract}

Kata kunci: Arus Kas Dan Nilai Perusahaan

\section{ABSTRACT}

They use the company's financial statements to measure the performance of the company, so that they know how the company's cash flow, and also can analyze and predict the financial potential that is owned by the company. The analytical method that being used is multiple linear regression. Conclusions from the study showed that simultaneous or partially cash flow does not affect the value of the company. Comparison of the two companies, in terms of cash flows based on the total activity during 2009, 2010 and 2013 PT Matahari Putra Prima Tbk was higher than PT Hero Supermarket Tbk, while for 2 years from 2011-2012 PT Hero Supermarket TBJ which is superior total operating activities compared with PT Matahari Putra Prima Tbk. Then based on the total investment activity, PT Matahari Putra Prima Tbk was higher than PT Hero Supermarket Tbk and based on the total funding activities PT Hero Supermarket Tbk was higher than Mathari PT Putra Prima Tbk. In 2009 and in 2013, PT Matahari Putra Prima Tbk yield ratio of price-book value $(P B V)$ is higher than the PT Hero Supermarket Tbk, whereas in 2010-2012 PT Hero Supermarket Tbk, which has a higher PBV ratio when compared to PT Matahari Putra Prima Tbk.

Key words: Cash Flow and Company's ptoportion

\section{Latar Belakang Masalah}

Pada umumnya, perusahaan diharuskan menyusun laporan keuangan yang baik dan benar untuk mengetahui arus kas masuk dan arus kas keluar selama satu periode. Di dalam laporan keuangan, banyak informasi yang disediakan temasuk informasi arus kas yang disediakan dalam laporan arus kas, sehingga para pemakai dari internal maupun eksternalnya perusahaan dapat mengetahui tumbuh kembang 
perusahaan tersebut dalam menghasilkan kas dan setara kas untuk kurun waktu tertentu.

Para pemakai laporan keuangan salah satunya adalah calon investor. Calon investor menggunakan laporan keuangan perusahaan untuk mengukur kinerja suatu perusahaan, sehingga mereka mengetahui bagaimana arus kas perusahaan, dan dapat menganalisis serta memprediksi potensi keuangan yang dimiliki oleh perusahaan tersebut baik atau tidak. Dari laporan keuangan tesebut, calon investor juga dapat menghitung dan menilai apakah suatu saham yang diedarkan oleh perusahaan mahal atau tidak, serta apakah modal yang ditanamkan oleh calon investor dapat menghasilkan keuntungan.

Para manajemen perusahaan akan menggunakan laporan keuangan untuk menilai asset nyata; menilai obligasi, saham serta perusahaan yang berguna juga untuk menilai harga saham dari merger dan akuisis yang dilakukan. Begitu juga dengan calon investor, mereka akan menggunkan laporan keuangan khususnya laporan arus kas untuk mengetahui berapa nilai perusahaan, serta mengetahui apakah harga saham perusahaan yang ada di pasar dinilai lebih (overvalue) atau dinilai kurang (undervalue), dibandingkan dengan perusahaan itu sendiri.

Tujuan dari penelitian ini adalah: 1) Untuk mengetahui bagaimana pengaruh arus kas terhadap nilai perusahaan pada PT Hero Supermarket, Tbk periode 2009-2013; 2) Untuk mengetahui bagaimana pengaruh arus kas terhadap nilai perusahaan pada PT Matahari Putra Prima, Tbk periode 2009-2013; 3) Untuk mengetahui bagaimana komparasiarus kas terhadap nilai perusahaan antara PT Hero Supermarket, Tbk dengan PT Matahari Putra Prima, Tbkperiode 2009-2013.

\section{Metodologi Penelitian}

Metode analisis data yang digunakan dengan menggunakan regresi linier berganda. Kemudian dilakukan uji asumsi klasik yang terdiri dari uji normalitas, uji multikolinearitas, uji heteroskedastisitas, dan uji autokorelasi. Selanjutnya dilakukan uji hipotesis yang terdiri dari analisis Uji Simultan (Uji F) dan Uji Parsial (Uji t), serta pengujian ini menggunakan software SPSS 20.

\section{Pembahasan}

Berdasarkan hasil pengolahan data di atas menunjukkan bahwa secara bersama-sama atau secara simultan variabel independen memiliki nilai signifikan. Dengan demikian, dapat disimpulkan bahwa arus kas operasi, total hutang dan pengeluaran modal secara bersama-sama tidak berpengaruh terhadap nilai perusahaan.

\subsection{Uji t (Uji Koefisien Regresi Secara Parsial) \\ 1. Pengujian Pengaruh Arus Kas Operasi Terhadap Nilai Perusahaan}

Sesuai dengan hasil pengujian statistik yang membandingkan antara t hitung dengan $t$ tabel. Arus kas operasi berpengaruh secara parsial terhadap nilai perusahaan.

2. Pengujian Pengaruh Total Hutang Terhadap Nilai Perusahaan

Sesuai dengan hasil pengujian statistik yang membandingkan antara $\mathrm{t}$ hitung dengan $\mathrm{t}$ tabel. Total hutang tidak berpengaruh secara parsial terhadap nilai perusahaan.

3. Pengujian Pengaruh Pengeluaran Modal Terhadap Nilai Perusahaan Sesuai dengan hasil pengujian statistik yang membandingkan 
antara $\mathrm{t}$ hitung dengan $\mathrm{t}$ tabel. Pengeluaran modal berpengaruh secara parsial terhadap nilai perusahaan.

\subsection{Persamaan Regresi Linier Berganda}

Berdasarkan hasil penelitian yang dilakukan, secara simultan rasio arus kas operasi, rasio total hutang dan rasio pengeluaran modal tidak berpengaruh terhadap price book value (PBV).

Hasil pengujian hipotesis secara parsial menunjukkan bahwa hanya rasio total hutang yang tidak memiliki pengaruh terhadap price book value (PBV), sedangkan rasio arus kas operasi dan rasio pengeluaran modal berpengaruh terhadap price book value (PBV).

Hasil penelitian secara simultan konsisten dibuktikan dengan hasil penelitian yang dilakukan oleh Debbianita dan Elyzabet I. Marpaung (2009) yang menyimpulkan bahwa laba per saham, total arus kas dan pendapatan secara bersama-sama tidak berpengaruh terhadap nilai perusahaan.

Rasio Price Book Value (PBV) pada Matahari tahun 2009 dan tahun 2013 lebih unggul, jika dibandingkan dengan rasio PBV pada Hero. Lalu pada tahun 2010 sampai tahun 2012, rasio PBV yang dihasilkan pada Hero lebih unggul bila dibandingkan dengan Matahari karena harga saham Hero juga dianggap mahal pada tahun tersebut, masing-masin Rp4.300,00 Rp11.000,00 dan Rp4.325,00.

\section{Kesimpulan}

Berdasarkan tujuan penelitian dan analisis data mengenai Komparasi Pengaruh Arus Kas Terhadap Nilai Perusahaan, maka dapat disimpulkan sebagai berikut:

1. Pengaruh arus kas terhadap nilai perusahaan pada PT Hero
Supermarket Tbk menghasilkan pengujian statistik bahwa secara simultan arus kas tidak memiliki pengaruh terhadap nilai perusahaan dan secara parsial hanya rasio total hutang yang tidak memiliki pengaruh terhadap nilai perusahaan, sedangkan rasio arus kas operasi dan rasio pengeluaran modal memiliki pengaruh terhadap nilai perusahaan pada PT Hero Supermarket Tbk periode 20092013.

2. Pengaruh arus kas terhadap nilai perusahaan pada PT Matahari Putra prima Tbk menghasilkan pengujian statistik bahwa secara simultan arus kas tidak memiliki pengaruh terhadap nilai perusahaan dan secara parsial hanya rasio total hutang yang tidak memiliki pengaruh terhadap nilai perusahaan, sedangkan rasio arus kas operasi dan rasio pengeluaran modal memiliki pengaruh terhadap nilai perusahaan pada PT Matahari Putra Prima Tbk periode 20092013.

3. Hasil komparasi dari kedua perusahaan yang dilakukan selama 5 tahun periode 2009-2013, yang dilihat dari arus kas pada aktivitas operasi, aktivitas investasi, aktivitas pendanaan, serta dari rasio price book value:

a. Dari segi total aktivitas operasi, pada tahun 2011 dan tahun 2012 PT Hero Supermarket Tbk lebih unggul total aktivitas operasinya. Hal ini dikarenakan bila dilihat dari sisi penjualan, PT Hero Supermarket Tbk mendapatkan penerimaan kas dari penjualan lebih tinggi dibandingkan dengan PT Matahari Putra Prima 
Tbk. Lalu pada tahun 20092010 dan tahun 2013, total arus kas aktivitas operasi PT Matahari Putra Prima Tbk lebih tinggi dibanding dengan PT Hero Supermarket Tbk.

b. Dari segi total aktivitas investasi, PT Matahari Putra Prima Tbk selalu lebih unggul dari pada PT Hero Supermarket Tbk. Hal ini disebabkan karena, PT Matahari Putra Prima Tbk dari tahun ke tahun selalu menerima pendapatan dari hasil penjualan asset tetap, hasil dari penjualan investasi jangka pendek, dan melakukan transaksi yang lainnya, sehingga itu yang menyebabkan perusahaan menghasilkan total aktivitas investasi yang lebih tinggi.

c. Dari segi total aktivitas pendanaan selama 5 tahun, PT Hero Supermarket Tbk yang lebih unggul dari PT Matahari Putra Prima Tbk. Hal ini dikarenakan, PT Hero Supermarket Tbk hanya melakukan pembayaran untuk membayar pinjaman dari bank maupun dari pihak berelasi, sedangkan PT Matahari Putra Prima Tbk melakukan pembayaran ke berbagai pihak, bukan hanya ke bank dan pihak berelasi tetap juga melakukan pembayaran dividen tunai kepada pemegang saham setiap tahunnya.

d. Jika dilihat pada tahun 2009 dan tahun 2013, rasio price book value (PBV) yang dimiliki oleh PT Matahari Putra Prima Tbk lebih tinggi, jika dibandingkan dengan PT

Hero Supermarket Tbk, sedangkan pada tahun 20102012 rasio PBV PT Hero Supermarket Tbk yang lebih tinggi dibanding dengan PT Matahari Putra Prima Tbk.

\section{DAFTAR PUSTAKA}

Darsono dan Ashari. 2005. Pedoman Praktis Memahami Laporan Keuangan, Andi, Yogyakarta.

Desmon Wira. 2011. Analisis Fundamental Saham, Exceed, Jakarta.

Duwi Priyatno. 2012. Cara Kiat Belajar Analisis Data dengan SPSS 20, ANDI, Yogyakarta.

Dwi Martani, dkk. 2012. Akuntansi Keuangan Menengah Berbasis PSAK, Salemba Empat, Jakarta.

Dwi Prastowo dan Rifka Julianty. 2008. Analisis Laporan Keuangan. AMP YKPN, Yogyakarta.

Eddy Mulyadi Soepardi. 2012. Metode Penelitian, Alpha Beta, Bandung.

Eddy Mulyadi Soepardi, dkk. 2014. Pedoman Seminar S1, Bogor: Universitas Pakuan (Diktat Kuliah).

Eugene, Brigham F. dan Houston, Joel F. 2010. Dasar-Dasar Manajemen Keuangan.Edisi 11. Penerjemah: Ali Akbar Yulianto, Salemba Empat, Jakarta.

Ikatan Akuntansi Indonesia. 2012. Standar Akuntansi Keuangan Per 1 Juni 2012, Jakarta.

Kamaludin dan Rini Indriani.2012.Manajemen

Keuangan "Konsep Dasar dan Penerapannya” Edisi Revisi, Mandar Maju, Bandung.

Lukas Setia Atmaja. 2008. Teori dan Praktek Manajemen Keuangan, Andi, Yogyakarta.

Mamduh M. Hadapi dan Abdul Halim. 2014. Analisis Laporan 
Keuangan., Edisi Keempat, UP STIM YKPN, Yogyakarta.

Munawir. 2002. Analisa Laporan Keuangan., Edisi Keempat, Liberty, Yogyakarta.

Sofyan Syafri Harahap. 2008. Analisa Kritis Atas Laporan Keuangan. Grafindo Persana, Jakarta.

Supardi U.S. 2013. Aplikasi Statistika Dalam Penelitian Edisi Revisi, Change Publication, Jakarta.

Van Horne, James C. 2007. PrinsipPrinsip Manajemen Keuangan,. Edisi 12, Salemba Empat, Jakarta.

Wild, John J., K.R. Subramanyam dan Robert F. Halsey. 2005. Analisis Laporan Keuangan: Buku 2. Edisi 8. Alih Bahasa: Yanivi S. Bachtiar dan S. Nurwahyu Harahap, Salemba Empat, Jakarta. 